\title{
Pengaruh Temperatur Sinter Terhadap Kekerasan dan Keausan Kampas Rem Berbasis Komposit Hibrida Serbuk Tempurung Kelapa/Alumina/Phenolic Resin
}

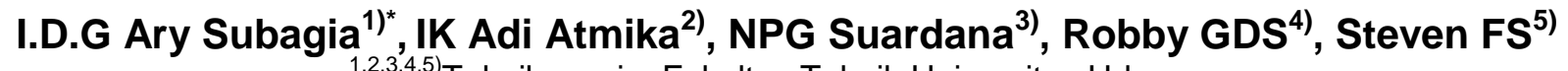 \\ ${ }_{1,2,3,4,5)}$ Teknik mesin, Fakultas Teknik Universitas Udayana \\ Kampus Bukit Jimbaran Badung Bali (80361) Indonesia
}

naskah masuk 07/06/018; diterima 15/10/2018; terbit 29/10/2018

doi: 10.24843/JEM.2018.v11.i02.p02

\begin{abstract}
Abstrak
Penelitian ini menginvestigasi sifat kekerasan dan keausan kampas rem komposit hibrida. Komposit hibrida berbasis penguat adalah serbuk tempurung Kelapa dan alumina dengan matriks phenolic resin. Benda uji diproduksi menggunakan hot press pada temperatur sinter bervariasi dari $200^{\circ} \mathrm{C}, 250^{\circ} \mathrm{C}$ dan $300^{\circ} \mathrm{C}$. Tujuan penelitian adalah menentukan tingkat kekerasan, laju keausan dan koefisien gesek dari komposit hibrida. Pengujian dilakukan dengan menggunakan pin-on-disk dan Vikers berdasarkan standar masing-masing ASTM E-92 dan ASTMG99-95a. Hasil pengujian ditunjukkan temperatur sinter telah signifikan menurunkan koefisien gesekan, walaupun pada benda uji A dengan temperatur sinter $200^{\circ} \mathrm{C}$ masih lebih tinggi dari benda uji control sebesar $3.54 \%$. Kemudian, nilai kekerasan HV untuk komposit hibrida pada temperatur sinter $300^{\circ} \mathrm{C}$ adalah 9.3\% lebih tinggi dari pada kontrol. Kesimpulan adalah komposit hibrida dengan komposisi $40 \%$ serbuk tempurung kelapa dan $20 \%$ alumina potensial diaplikasikan untuk bahan alternatif kampas rem kendaraan bermotor.
\end{abstract}

Kata kunci: Kekerasan, Keausan, Komposit Hibrida, Kampas Rem, Sinter

\section{Abstract}

This research investigates the hardness and wear behavior of hybrid composite brake pad. Hybrid composite was manufactured base on particles coconut cell and alumina reinforced and phenolic resin matrix. The specimens were produced by using the hot press according to temperatures variation of $200^{\circ} \mathrm{C}, 250^{\circ} \mathrm{C}$ and $300^{\circ} \mathrm{C}$. The research purpose to determine hardness ability, wear rate, and friction coefficient of hybrid composites. Pin-on-disk and Vickers test have been employed according to the ASTM E-92 dan ASTMG99-95a, respectively. The result shows that sintering temperature have been significant decreased friction coefficient, while on specimen $\mathrm{A}$ with $200^{\circ} \mathrm{C}$ sinter temperature has $3.54 \%$ higher than control specimen. In addition, the hardness (HV) number of hybrid composite on $300^{\circ} \mathrm{C}$ sinter temperatures has $9.3 \%$ higher than control. Conclusion, hybrid composite with composition $40 \%$ coconut cell particles and $20 \%$ alumina has potential as alternative material of the vehicle brake pad application.

Keywords: Hardness, wear, hybrid composite, brake pad, sintering

\section{Pendahuluan}

Kampas rem merupakan komponen utama sistem rem, yang berfungsi memberikan gesekan, sehingga laju kendaraan bermotor dapat diperlambat. Kampas rem merupakan material komposit yang terdiri dari bahan logam dan asbes sebagai penguat dengan phenolic resin sebagai matrik. Asbes adalah bahan terpenting dari kampas rem karena bersifat stabil terhadap temperatur [1]. Saat ini, penggunaan bahan asbes pada kampas rem mulai dikurangi dan bahkan ditiadakan karena bersifat karsinogenik yang dapat menyebabkan gangguan pernapasan pada manusia dan berlanjut menjadi kanker paru-paru [2]. Sejak tiga dekade terakhir, kampas rem telah diproduksi menggunakan bahan organik [3] dengan tujuan menurunkan dampak lingkungan yang ditimbulkan.

Komposit hybrid merupakan salah satu metode yang diaplikasikan dalam pembuatan kampas rem yang kuat, alami dan mudah daur ulang, serta murah. Banyak penelitian terkait performance dan sifat ramah lingkungan bahan kampas rem dilakukan oleh Yun [4]. Sedangkan Kumar, dkk [5] mengembangkan material gesek komposit dengan penguat kombinasi potassium titanate whisker dan serat aramid. Purboputro [6] meneliti ketahanan aus dan karakteristik pengereman dari kampas rem dengan komposit serat bamboo fiber glass, sebuk aluminum, polyester matrik. Idris, dkk [3] mempelajari material kampas rem yang ramah lingkungan menggunakan bahan kulit pisang, yang dihasilkan serbuk kulit pisang dapat menjadi salah satu bahan alternative pengganti asbestos pada struktur kampas rem kendaraan bermotor. Sifat mekanik dari komposit berpenguat batok kelapa matrik polymer diamati oleh [7]. Kemudian, keausan, gesekan dan kekerasan dari kampas rem berbasis material non-asbestos telah diteliti oleh [8-12]. Camacho [13] mempelajari dan mendeskripsikan keausan mekanis dari kampas rem. Sedangkan sifat tribology dari kampas rem diperkuat partikel alumina matrik alumunium di pelajari oleh [14] dan pengujian dengan screening test untuk tribology bahan kampas rem kendaraan di uji oleh [15]. Kemudian komposit hibrida untuk pengereman kendaraan menggunakan analitik hirarky process di pelajari oleh [16]. 
Permasalahan utama dari kampas rem dengan bahan komposit adalah pada tingkat ke ausan dan kekerasan. Kedua sifat ini sangat berpengaruh pada kualitas koefisien gesekan yang dihasilkan. Sehingga, sangat perlu dilakukan kajian terhadap kampas rem dengan bahan organic. Pada kesempatan ini, penelitian dilakukan untuk kampas rem dengan penguat hibrida $20 \%$ serbuk tempurung kelapa dan alumina. Sebagai matrik adalah phenolic resin. Tujuan penelitian adalah menginvestigasi kekerasan dan keausan dari kampas rem hibrida yang diproduksi menggunakan hot-press untuk tiga variasi temperatur $\left(150^{\circ} \mathrm{C}, 200^{\circ} \mathrm{C}\right.$ dan $\left.250^{\circ} \mathrm{C}\right)$. Pengujian dilakukan dengan metode Vikers (HVN) untuk kekerasan permukaan bahan dan pin-on-disk untuk laju keausan bahan kampas rem. Analisa mikroskopic bahan dilakukan menggunakan scanning electron mikroskop (SEM).

\section{Metode Penelitian}

\subsection{Material}

Komposit hibrida terdiri dari dua penguat berupa partikel yaitu serbuk tempurung kelapa dan alumina. Komposisi dari kedua partikel adalah 40\% serbuk tempurung kelapa dan $20 \%$ alumina. Bentuk dan ukuran butir dari tempurung kelapa dan alumina adalah seragam dengan ukuran 100 mesh. Tempurung kelapa merupakan material organik yang mengandung Lignin 29,40\%, Pentosan 27,70\%, Selulosa $26,60 \%$, Air $8,00 \%$, Solvent ekstraktif 4,20\%, Uronat Anhidrat 3,50\%, Abu $0,60 \%$ dan Nitrogen $0,10 \%$. Sedangkan Alumina dengan rumus kimia $\mathrm{Al}_{2} \mathrm{O}_{3}$ memiliki densitas: $3,95 \mathrm{gr} / \mathrm{cm}^{3}$, titik leleh $2072^{\circ} \mathrm{C}$, titik didih $2977^{\circ} \mathrm{C}$, dan konduktivitas termal $30 \mathrm{Wm}^{-1} \mathrm{~K}^{-1}$. Alumina diproduksi oleh PT.INALUM. Disamping itu alumina memiliki kekerasan yang tinggi sehingga banyak dimanfaatkan sebagai abrasive dan komponen alat pemotong. Alumina mengandung maksimum berturut-turut $0.03 \% \mathrm{SiO}_{2}, 0.03 \% \mathrm{Fe}_{2} \mathrm{O}_{3}, 0.005 \% \mathrm{TiO}_{2}$, $0.600 \% \mathrm{Na}_{2} \mathrm{O}, 0.060 \% \mathrm{CaO}$ dan minimum $98.4 \% \mathrm{Al}_{2} \mathrm{O}_{3}$. Matrik dipergunakan adalah phenolic resin yang diproduksi oleh PT. Indopherin Jaya, dengan nama produk sumiliteresin PR-51510 I. Density phenolic resin adalah $1.15 \mathrm{gr} / \mathrm{cm}^{3}$. Modulus Young $3 \mathrm{GPa}$, dan Kekuatan tarik 50GPa. Selain itu, phenolic resin memiliki titik leleh 160 oC.

Ketiga bahan yang digunakan dalam pembuatan komposit hibrida untuk kampas rem kendaraan bermotor ditunjukkan seperti pada gambar 1a, b dan $\mathrm{c}$.

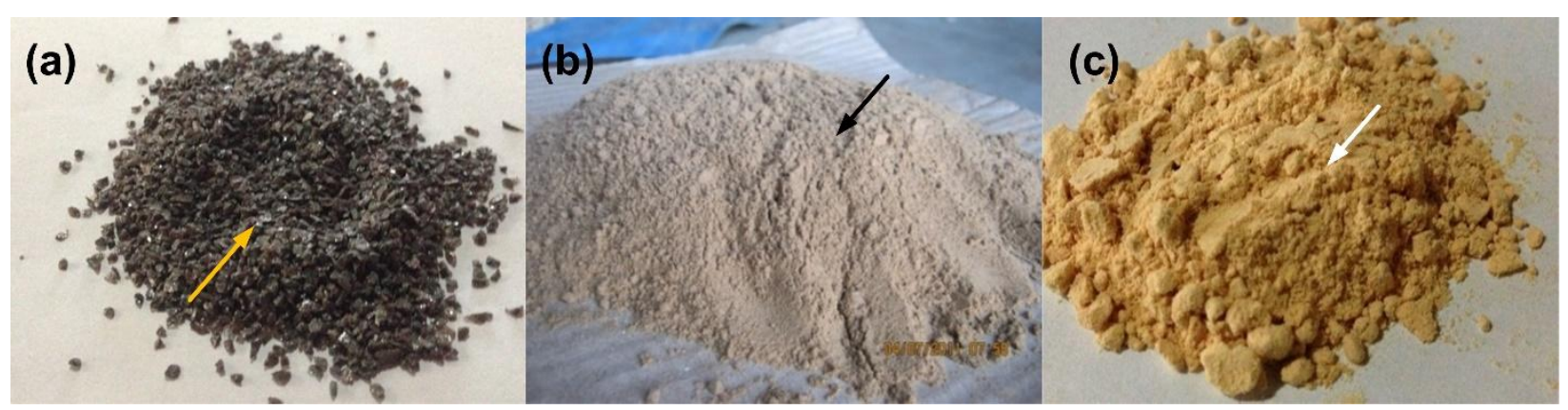

Gambar 1 a. alumina, b bubuk tempurung kelapa, c phenolic resin
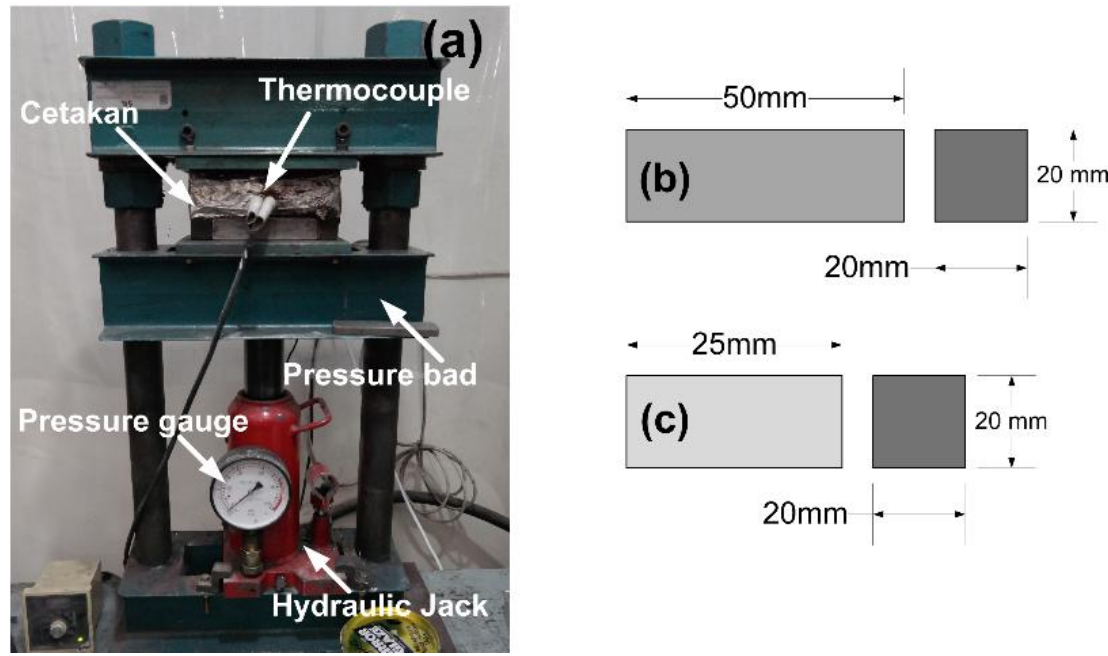

Gambar 2 a mesin hot-press, b Geometri benda uji kekerasan, c Geometri benda uji keausan 


\subsection{Proses fabrikasi}

Pada pembuatan kampas rem teknik hot press telah dilakukan dengan variasi suhu $200^{\circ} \mathrm{C}, 250^{\circ} \mathrm{C}$ dan $300^{\circ} \mathrm{C}$, masing - masing. Pembebanan pada proses hot press adalah konstan sebesar $3000 \mathrm{~N}$. Proses hot press ditunjukkan seperti pada Gambar 2a. Sedangkan geometri benda kerja ditunjukkan pada gambar $2 b$.

Pengujian kekerasan dan keausan dilakukan masing-masing berdasarkan pada standard ASTM E92 dan ASTMG99-95a 2000. Pengujian kekerasan dilakukan menggunakan mesin Vickers (HVN), menggunakan dentor diamond dengan beban $1000 \mathrm{~N}$ yang diamati dengan lensa okuler pembesaran 10xx.

Penghitungan kekerasan dan laju keausan dari kampas rem dengan material komposit hibirda untuk masing-masing perlakuan temperatur hot-press dihitung menggunakan persamaan sebagai berikut; Laju keausan komposit hibrida $k^{I}=\frac{w_{0}-w_{1}}{s}$

Faktor keausan ditentukan dengan persamaan;

$$
\text { Faktor keausan }=\frac{\text { Vol.Keausan }\left(\mathrm{mm}^{\mathrm{a}}\right)}{\text { Beban }(\text { N) } \times \text { Jarak tempuh }(\mathrm{m})}
$$

Bentuk penampang terhadap keausan

$P=a . l ; l=\frac{\pi \cdot r \cdot \varphi}{180^{2}}$

Kehilangan massa perluas penampang ditentukan dengan persamaan;

$z=\frac{m}{p}\left(\frac{g r}{c m^{3}}\right)$

Koeffisien gesekan kampas rem ditentukan dengan persamaan;

$\mu_{s}=\frac{F_{a^{*} b} / a}{F}=\frac{F_{S}}{F}$

Dimana; $F_{a}$ adalah gaya yang dibebankan pada alat $(\mathrm{N}), b$ jarak tumpuan ke beban pada alat $(\mathrm{mm}), a$ jarak tumpuan ke gaya statis $(\mathrm{mm}), F_{s}$ adalah gaya gesek (N), $\mu_{s}$ menunjukkan koeffisien gesekan. $k^{\prime}$ adalah laju keausan, $w_{o}$ berat awal benda uji (gr), $w_{1}$ berat akhir benda uji ( $\mathrm{gr}$ ) dan $s$ jarak tempuh (m). Kemudian, $P$ adalah keausan permukaan ditentukan menurut penampang. Pada penelitian ini dipergunakan penampang spherical. a menunjukkan lebar benda uji, $l$ panjang port.

Pengujian kekerasan Vikers dari benda uji dihitung menggunakan persamaan

$H V N=\frac{1.854 \times p}{d^{2}}$

Dimana; HVN adalah Vickers hardness number, $\mathrm{P}$ adalah beban penekanan $(\mathrm{N})$, dan d Panjang diagonal indentasi $(\mathrm{mm})$.

Fabrikasi komposit hibrida dengan penguat partikel serbuk tempurung kelapa dan alumina didasarkan pada rasio fraksi berat yaitu $40 \%$ dan $20 \%$ masing masing. Sedangkan rasio fraksi berat komposit adalah $60 \%$ penguat dan $40 \%$ matrik. Perhitungan fraksi berat komposit ditentukan dengan persamaan;

$x(\%)=\frac{\sum w_{f}}{\sum w_{f}+\sum w_{m}}$

Dimana; $X$ adalah fraksi berat $(\%), w_{f}$ berat fiber (gr), $w_{m}$ adalah berat matrik (gr)

\section{Hasil dan pembahasan}

\subsection{Keausan kampas rem komposit hibrida}

Gambar 3 menunjukkan grafik hubungan keausan dengan jarak tempuh. Dapat diamati bahwa semakin panjang jarak tempuh maka keausan yang terjadi pada kampas rem komposit hibrida partikel serbuk kelapa/alumina/phenolic resin meningkat secara beraturan. Berdasarkan hasil pengujian tersebut, titik pengujian terbaik adalah pada jarak 300 $\mathrm{m}$, dengan beban tetap $20 \mathrm{~N}$ pada kecepatan $150 \mathrm{rpm}$ dimana pada jarak tersebut, keausan yang terjadi stabil.

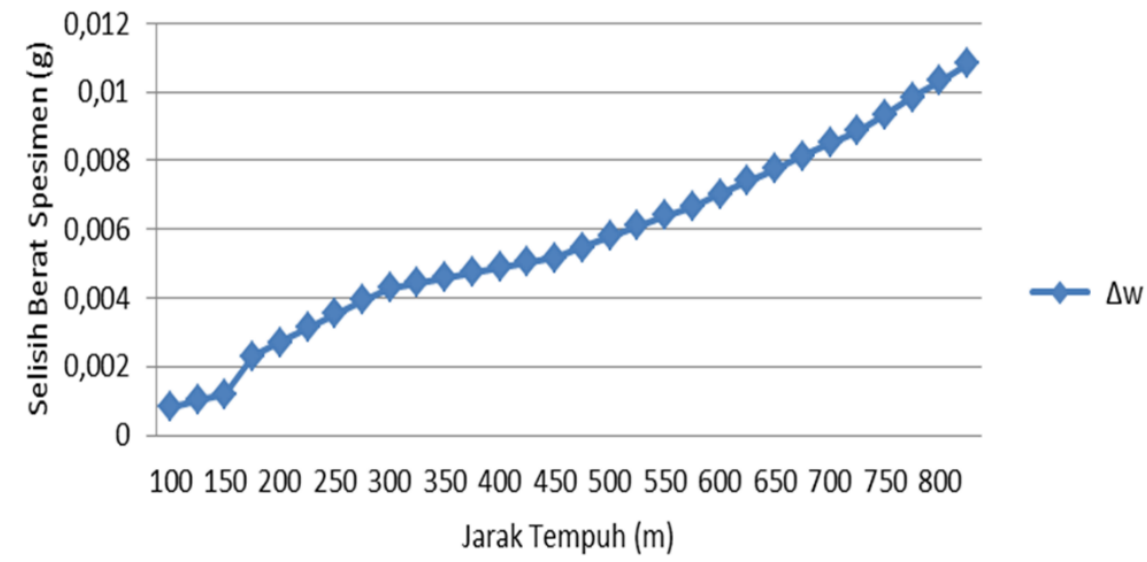

Gambar 3 Hubungan jarak tempuh dengan selisih berat specimen pada uji pin-on-disk 
Gambar 4 menginformasikan laju keausan dari kampas rem komposit hibrida untuk masing-masing perlakuan temperatur dari komposit hibrida yaitu huruf kapital A adalah benda uji yang di sinter pada temperatur $200^{\circ} \mathrm{C}$, huruf $\mathrm{B}$ adalah benda uji yang disinter pada temperatur $250^{\circ} \mathrm{C}$ dan huruf $\mathrm{C}$ adalah benda uji yang di sinter pada temperatur $300^{\circ} \mathrm{C}$, sedangkan huruf $X$ adalah kampas rem dengan bahan asbes sebagai kontrol. Diamati pada gambar bahwa, laju keausan terbesar adalah terjadi pada benda uji $\mathrm{A}$ yaitu $0.000116 \mathrm{gr} / \mathrm{m}^{3}$. Sedangkan pada benda uji B, C dan $X$ berturut-turut sebesar $0.000077 \mathrm{gr} / \mathrm{m}^{3}$, $0.000067 \mathrm{gr} / \mathrm{m}^{3}$ dan $0.000075 \mathrm{gr} / \mathrm{m}^{3}$. Sesuai dengan ketahanan masing-masing bahan pembentuk hibrida komposit terhadap perlakuan suhu, dihasilkan pada temperatur $300^{\circ} \mathrm{C}$ (benda uji C) memiliki keausan terendah terhadap kontrol yaitu $10.67 \%$. Temperatur sinter yang tinggi mengakibatkan serbuk tempurung kelapa terbakar, karena temperatur maksimum yang diijinkan untuk tempurung kelapa adalah lebih rendah dari $200^{\circ} \mathrm{C}$. Dengan demikian hanya terjadi ikatan antara alumina dan penoloic resin yang mengakibatkan permukaan gesek menjadi sangat halus.

Selanjutnya, nilai koefisien gesek dari benda uji $A$, B C dan X berturut - turut adalah 0.226; 0.205; 0.199; dan 0.218. Diamati dari bahan kampas rem $X$ semakin tinggi temperatur sinter telah signifikan menurunkan koefisien gesekan, walaupun pada benda uji A dengan temperatur sinter $200^{\circ} \mathrm{C}$ masih lebih tinggi dari benda uji control sebesar 3.54\%. Dapat disimpulkan bahwa temperatur sinter berpengaruh signifikan terhadap penurunan nilai laju keausan dan koefisien gesekan dari komposit hibrida sebagai bahan kampas rem kendaraan bermotor. Pendapat yang sama juga ditunjukkan oleh [17-19].

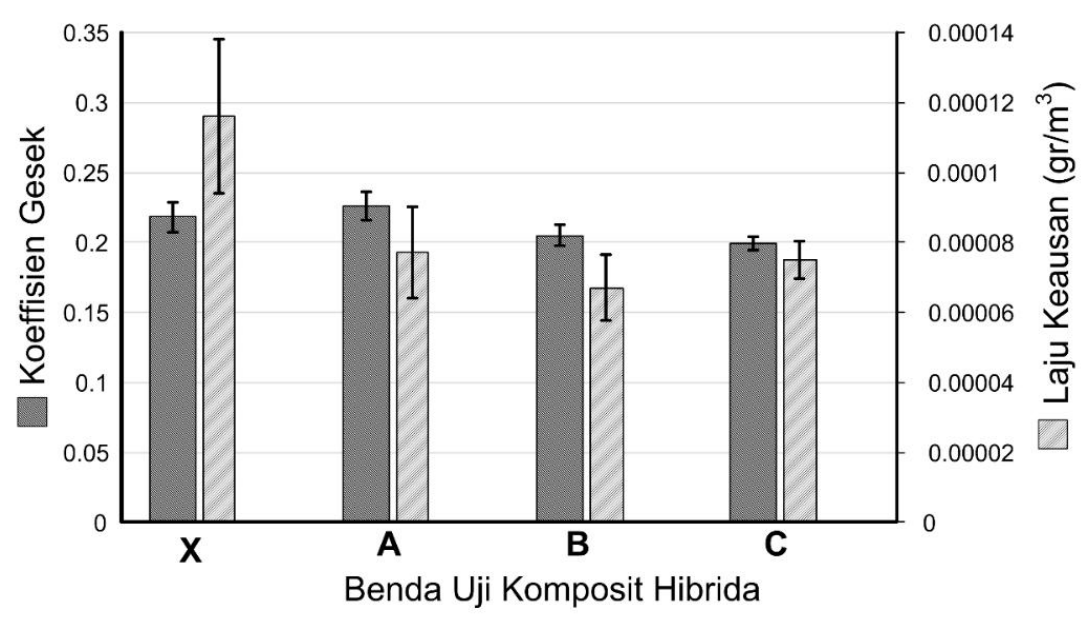

Gambar 4 Nilai koefisien gesek dan laju keausan benda uji komposit hibrida pada pada variasi temperatur sinter $\mathrm{A}: 200^{\circ} \mathrm{C}, \mathrm{B}: 250^{\circ} \mathrm{C}$ dan $\mathrm{C}: 300^{\circ} \mathrm{C}, \mathrm{X}$ benda uji kontrol

\subsection{Kekerasan Kampas rem komposit hibrida}

Kekerasan dijelaskan sebagai salah satu sifat mekanik dari suatu material yang akan mengalami pergesekan (frictional force) dan deformasi plastis. Dengan kata lain, kekerasan adalah kemampuan suatu material untuk menahan beban identasi atau penekanan (penetrasi). Kekerasan material komposit hibrida partikel serbuk kelapa/alumina/phenolic resin ditunjukkan seperti pada Gambar 5. Tiga benda uji dengan variasi temperatur sinter masing-masing benda uji $\mathrm{A}, \mathrm{B}$ dan $\mathrm{C}$ berturut-turut pada temperatur $200^{\circ} \mathrm{C}, \quad 250^{\circ} \mathrm{C}$ dan $300^{\circ} \mathrm{C}$ telah dikerjakan dibandingkan kekerasannya terhadap benda uji $\mathrm{X}$ sebagai kontrol. Diamati dari hasil pengujian seperti pada gambar 5 dijelaskan bahwa kenaikan temperatur sinter sangat berperan penting pada nilai kekerasan dari benda uji komposit hibrida. Semakin tinggi temperatur sinter komposit hibrida nilai kekerasan meningkat secara linier. Nilai kekerasan berturut turut untuk benda uji A, B dan C adalah 90.88HV 20/15, 99.15HV 20/15 dan 107HV 20/15. Kemudian untuk kekerasan material kontrol adalah 97.10HV 20/15. Berdasarkan hasil pengujian bahwa pada temperatur sinter $300^{\circ} \mathrm{C}$ lebih tinggi nilai kekerasan terhadap kontrol sebesar 9.3\%. Hasil menunjukkan komposit hybrid dengan komposisi $40 \%$ serbuk tempurung kelapa dan $20 \%$ alumina potensial diaplikasikan sebagai bahan alternatif kampas rem kendaraan bermotor. 


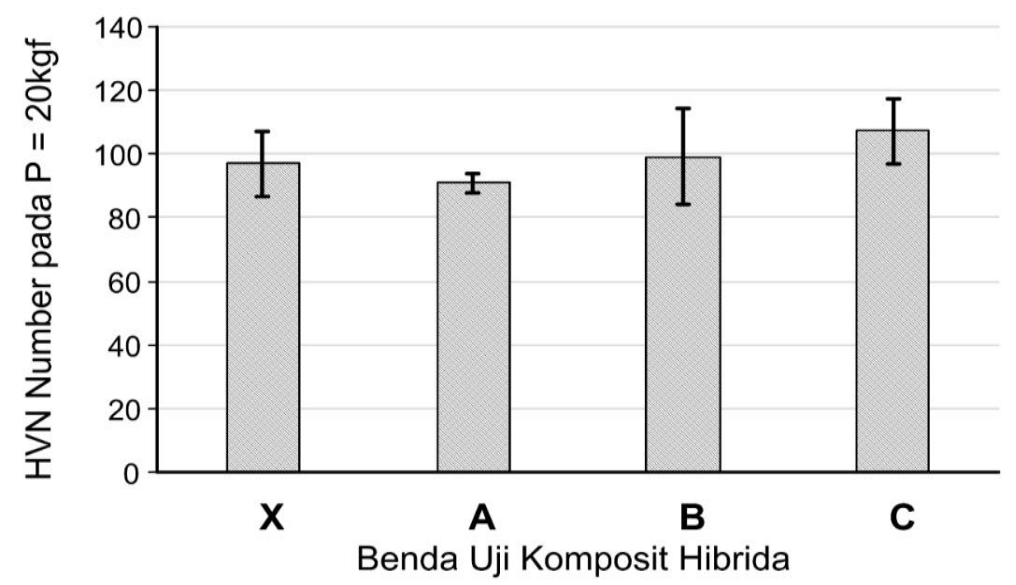

Gambar 5 nilai HVN komposit hibrida pada variasi temperatur sinter yaitu $\mathrm{A}: 200^{\circ} \mathrm{C}, \mathrm{B}: 250^{\circ} \mathrm{C}$ dan $\mathrm{C}: 300^{\circ} \mathrm{C}, \mathrm{X}$ benda uji kontrol

\subsection{Analisa mikro struktur kampas rem komposit hibrida}

Ikatan antar partikel oleh matrik pada struktur komposit hibrida menjadi sangat penting. Ikatan yang massive dari struktur material komposit sangat berpengaruh pada sifat mekanis khususnya kekerasan dan keausan akibat gesekan [5]. Gambar 6 menunjukkan karakteristik ikatan dari partikel alumina dan tempurung kelapa pada matrik phenolic resin untuk masing-masing perlakuan panas sinteran. Hasil pengamatan dengan menggunakan mikroskop electron pada pembesaran $5 \mathrm{X}$ untuk masing - masing temperatur sinter dari benda uji terlihat banyak timbul porositas yang disebabkan oleh sebagian dari partikel tempurung kelapa terbakar. Semakin tinggi temperatur sinter tingkat porositas dan luas penampang pori meningkat. Kondisi ini telah berpengaruh signifikan terhadap karakteristik laju keausan, kekerasan dan koefisien gesek dari benda uji.
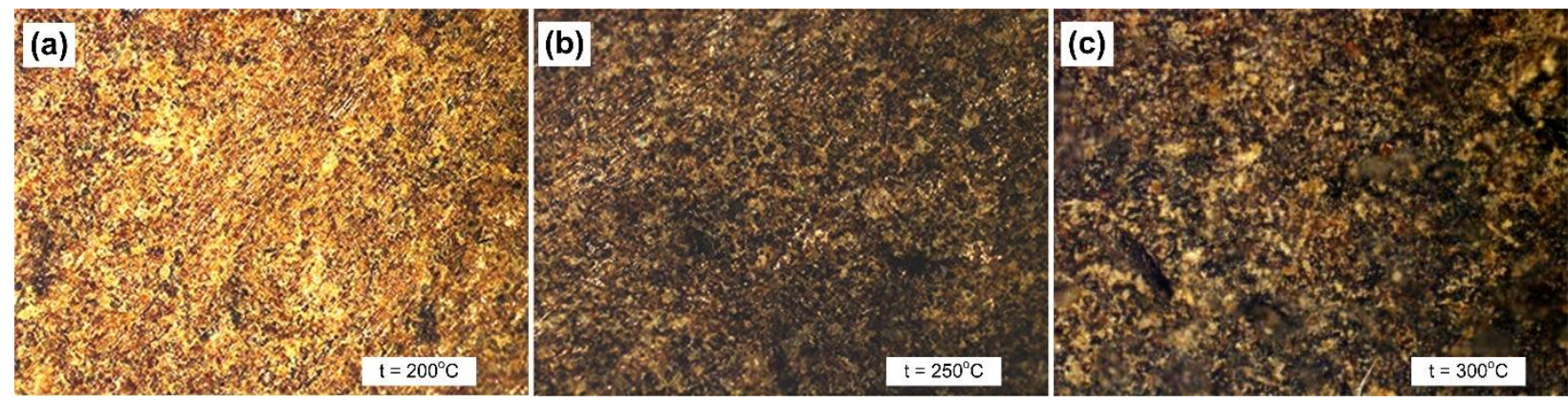

Gambar 6. Gambar penampang komposit hibrida menggunakan mikroskop electron pembesaran pada 5X; ( ). benda uji pada temperatur sinter $200^{\circ} \mathrm{C}$; (b) benda uji pada temperatur sinter $250^{\circ} \mathrm{C}$; (c) benda uji pada temperatur sinter $300^{\circ} \mathrm{C}$ 


\section{Simpulan}

Penelitian ini memproduksi kampas rem kendaraan bermotor berbasis komposit hibrida partikel tempurung kelapa dan alumina dengan phenolic resin matrik. Benda uji diproduksi melalui proses hot-press pada temperatur yaitu $200^{\circ} \mathrm{C}$, $250^{\circ} \mathrm{C}$ dan $300^{\circ} \mathrm{C}$ dengan beban $3000 \mathrm{~N}$. Pengujian pin-on-disk pada beban $20 \mathrm{~N}$ dengan kecepatan 150 Rpm untuk laju keausan dan Hardness Vickers Number (HVN) untuk uji kekerasan dengan beban 20 kgf selama 15 menit telah dilakukan untuk setiap benda uji. Pengujian dilakukan sebanyak lima kali untuk masing - masing benda uji berdasarkan standar ASTM. Hasil pengujian laju keausan, koefisien gesek dan kekerasan komposit hibrida telah dihasilkan, sehingga dapat disimpulkan;

1. Temperatur sinter telah signifikan menurunkan koefisien gesekan, walaupun pada benda uji A dengan temperatur sinter

2. $200^{\circ} \mathrm{C}$ masih lebih tinggi dari benda uji control sebesar $3.54 \%$.

3. temperatur sinter $300^{\circ} \mathrm{C}$ lebih tinggi nilai kekerasan terhadap kontrol sebesar $9.3 \%$.

4. temperatur sinter dari benda uji terlihat banyak timbul porositas yang disebabkan oleh sebagian dari partikel tempurung kelapa terbakar.

5. Hasil menunjukkan komposit hybrid dengan komposisi $40 \%$ serbuk tempurung kelapa dan $20 \%$ alumina potensial diaplikasikan sebagai bahan alternatif kampas rem kendaraan bermotor.

\section{Ucapan Terima Kasih}

Penulis mengucapkan banyak terima kasih kepada Lembaga penelitian dan pengabdian kepada Masyarakat Universitas Udayana sebagai penyandang dana.

\section{Daftar Pustaka}

[1] Hossein KAKOOEI, Mahmod SAMETI, A.A. KAKOOEI, Asbestos Exposure during Routine Brake Lining Manufacture, Industrial Health 45 (2007) 787-792.

[2] R.U. Rao, G. Babji, A Review paper on alternate materials for Asbestos brake pads and its characterization, (2015).

[3] U.D. Idris, V.S. Aigbodion, I.J. Abubakar, C.I. Nwoye, Eco-friendly asbestos free brake-pad: Using banana peels, Journal of King Saud University - Engineering Sciences 27 (2015) 185-192.

[4] R. Yun, P. Filip, Y. Lu, Performance and evaluation of eco-friendly brake friction materials, Tribology International 43 (2010) 2010-2019.
[5] M. Kumar, B.K. Satapathy, A. Patnaik, D.K. Kolluri, B.S. Tomar, Hybrid composite friction materials reinforced with combination of potassium titanate whiskers and aramid fibre: Assessment of fade and recovery performance, Tribology International 44 (2011) 359-367.

[6] P.I. Purboputro, Pengembangan Kampas Rem Sepeda Motor Dari Komposit Serat Bambu, Fiber Glass, Serbuk Aluminium Dengan Pengikat Resin Polyester Terhadap Ketahanan Aus Dan Karakteristik Pengeremannya Seminar Nasional Aplikasi Sains \& Teknologi (SNAST) Periode III Yogyakarta, 2012 pp. 367373.

[7] J. Olumuyiwa Agunsoye, Talabi S. Isaac, S.O. Samuel, Study of Mechanical Behaviour of Coconut Shell Reinforced Polymer Matrix Composite, Journal of Minerals and Materials Characterization and Engineering 11 (2012) 774-779.

[8] S. Balaji, K. Kalaichelvan, Optimization of a Non Asbestos Semi Metallic Disc Brake Pad Formulation with Respect to Friction and Wear, Procedia Engineering 38 (2012) 1650-1657.

[9] S.W. Yoon, M.W. Shin, W.G. Lee, H. Jang, Effect of surface contact conditions on the stick-slip behavior of brake friction material, Wear 294295 (2012) 305-312.

[10] K. W. Liew, Umar Nirmal, Frictional performance evaluation of newly designed brake pad materials, Materials \& Design 48 (2013) 25-33.

[11] Poh Wah Lee, P. Filip., Friction and wear of Cufree and Sb-free environmental friendly automotive brake materials, Wear 302 (2013) 1404-1413.

[12] Faris M. AL-Oqla, S.M. Sapuan., Natural fiber reinforced polymer composites in industrial applications: feasibility of date palm fibers for sustainable automotive industry, Journal of Cleaner Production 66 (2014) 347-354.

[13] J.R. Laguna-Camacho, G. Juárez-Morales, C. Calderón-Ramón, V. Velázquez-Martínez, I. Hernández-Romero, J.V. Méndez-Méndez, M. Vite-Torres, A study of the wear mechanisms of disk and shoe brake pads, Engineering Failure Analysis 56 (2015) 348-359.

[14] F. Ahmad, S.H.J. Lo, M. Aslam, A. Haziq, Tribology Behaviour of Alumina Particles Reinforced Aluminium Matrix Composites and Brake Disc Materials, Procedia Engineering 68 (2013) 674-680.

[15] W. Österle, C. Deutsch, T. Gradt, G. Orts-Gil, T. Schneider, A.I. Dmitriev, Tribological screening tests for the selection of raw materials for automotive brake pad formulations, Tribology International 73 (2014) 148-155.

[16] M.R. Mansor, S.M. Sapuan, E.S. Zainudin, A.A. Nuraini, A. Hambali., Hybrid natural and glass fibers reinforced polymer composites material selection using Analytical Hierarchy Process for automotive brake lever design, Materials and Design 51 (2013) 484-492. 
[17] G.-P. Ostermeyer, M. Graf, Influence of wear on thermoelastic instabilities in automotive brakes, Wear 308(1-2) (2013) 113-120.

[18] M. Kchaou, A. Sellami, R. Elleuch, H. Singh, Friction characteristics of a brake friction material under different braking conditions, Materials \& Design 52 (2013) 533-540.

[19] D. Gultekin, M. Uysal, S. Aslan, M. Alaf, M.O. Guler, H. Akbulut, The effects of applied load on the coefficient of friction in Cu-MMC brake $\mathrm{pad} / \mathrm{Al}-\mathrm{SiCp}$ MMC brake disc system, Wear 270 (2010) 73-82. 